\title{
Studies of Genetic and Morphological Characteristics of Indonesian Melon (Cucumis melo L. 'Hikapel') Germplasm
}

\author{
Adib Fakhruddin Yusuf a, Budi Setiadi Daryono a, ${ }^{\text {a }}$ \\ ${ }^{a}$ Faculty of Biology, Universitas Gadjah Mada, Yogyakarta, Indonesia \\ Corresponding author: ${ }^{*} b s$ daryono@mail.ugm.ac.id
}

\begin{abstract}
The abundance of biodiversity in Indonesia is due to variations in germplasm and the diversity of plant species. Due to the high potential and demand for melons, it is necessary to innovate the assembly of superior varieties through a plant breeding approach. Here, we report the identification of phenotypic and genotypic traits with their phenetic relationships to determine the premium characteristics of the new melon cultivar - Hikapel. Observation of morphological characters using observational studies, qualitative descriptive, and quantitative identification at two cultivation locations: (1) Prambanan, Sleman Regency, Yogyakarta, and (2) Pangalengan, Bandung Regency, West Java. Meanwhile, molecular character testing uses the ISSR markers UBC-807, UBC-808, UBC810, UBC-812, and UBC-825. Morphological character data were analyzed using SPSS one-way ANOVA with LSD and Duncan tests. All data were grouped based on similarity values using cluster analysis of the multi-variate statistical package (MVSP 3.1) to determine the tested kinship relationship between the varieties. The results showed that Hikapel has several diagnostic characters as a new variety, namely: globular shape with cream-colored skin, aromatic fruit, small size, high sweetness level, and short harvest time. The stability and uniformity test results those characters of Hikapel can be maintained at various locations. This research can serve as basic data for developing melon varieties based on genomic data and aims as an initial step in the innovation of Indonesian Agriculture.
\end{abstract}

Keywords - Stability; inter-simple sequence repeat; Hikapel; variety.

Manuscript received 21 Dec. 2020; revised 18 Mar. 2021; accepted 23 Apr. 2021. Date of publication 31 Oct. 2021. IJASEIT is licensed under a Creative Commons Attribution-Share Alike 4.0 International License.

\section{INTRODUCTION}

Biodiversity spreads across the world, with the highest concentration in tropical countries and the oceans. Biodiversity data collection is crucially important because it describes the country's biological wealth [1]. There has been much biodiversity data collected through specimens as the initial biodiversity studies by taxonomists [2]. Unfortunately, taxa data collection under species is not enough, especially plant cultivars managed by local ministries of agriculture such as Indonesia.

Along with the uncontrolled and unpredictable global climate development, conventional farmers in Indonesia must face worsening production conditions [3]. Pest variety and resistance are also obstacles that can reduce the quality and quantity of products [4]. Not to mention, the product requirements are increasingly varied and challenging. Such as taste preferences, fruit colors, and unique characters that need special attention [5]. These numerous factors have become benchmarks for consumer confidence in commercial melon products and scientific developments in Indonesia.
Research on superior physiological characteristics of melons like disease resistance due to Fusarium in Tunisian Genotypes [6] and salinity [7]. Even now, the general function of melons has expanded; melons are not only edible fruit but also a cosmetic raw material (non-edible). Recently, it has been reported that the melon variety GMP (Gama Melon Parfum) has a bitter taste with the accumulation of a terpene derivative, Cucurbitacin [8].

Therefore, as a country with extensive biodiversity, especially melons. Indonesia has many sources of germplasm to assemble various superior cultivar melons. Therefore, it is important to collect data and manage germplasm, through the right to protect plant varieties [9]. Genotype evaluations are needed for new varieties produced. Therefore, there is a requirement that a plant can be called a new cultivar; stable, uniform, unique and new. This study aims to determine the superior character of Hikapel as a new melon cultivar with the phenetic relationship with commercial cultivars based on morphological and molecular characters. 


\section{MATERIALS AND METHODS}

\section{A. Preliminary Research Preparation}

Research preparation is carried out at the Laboratory of Genetics and Breeding, Faculty of Biology, UGM. The tools used in this research include cultivation tools and data collection tools. Tools for data collection include a ruler, calipers, hand refractometer, scissors, and RHS color chart. The seeds used in this study consisted of Hikapel candidate melon seeds and commercial melon seeds. Hikapel seed is a hybrid melon from breeding. Meanwhile, comparable commercial melon seeds (Alisha, Moonlight, Kirani, Kinanti, and Sonya) are seeds purchased from traders.

The cultivation of the melon population was carried out in two different locations. (1) Greenhouse Nudira, Pangalengan District, Bandung, West Java and (2) Screenhouse Mutihan, Madurejo District, Sleman, Yogyakarta Special Region from July to October 2019. This study used a Randomized Block Design (RBD) which consist of 6 cultivar treatments and 2 location treatment. Each replicate block contains 40 plants in double rows with a spacing of $10 \mathrm{~cm} \times 30 \mathrm{~cm}$. The total population of plants used for the study was 720 individuals with 120 plants in every variety and divided into three replications.

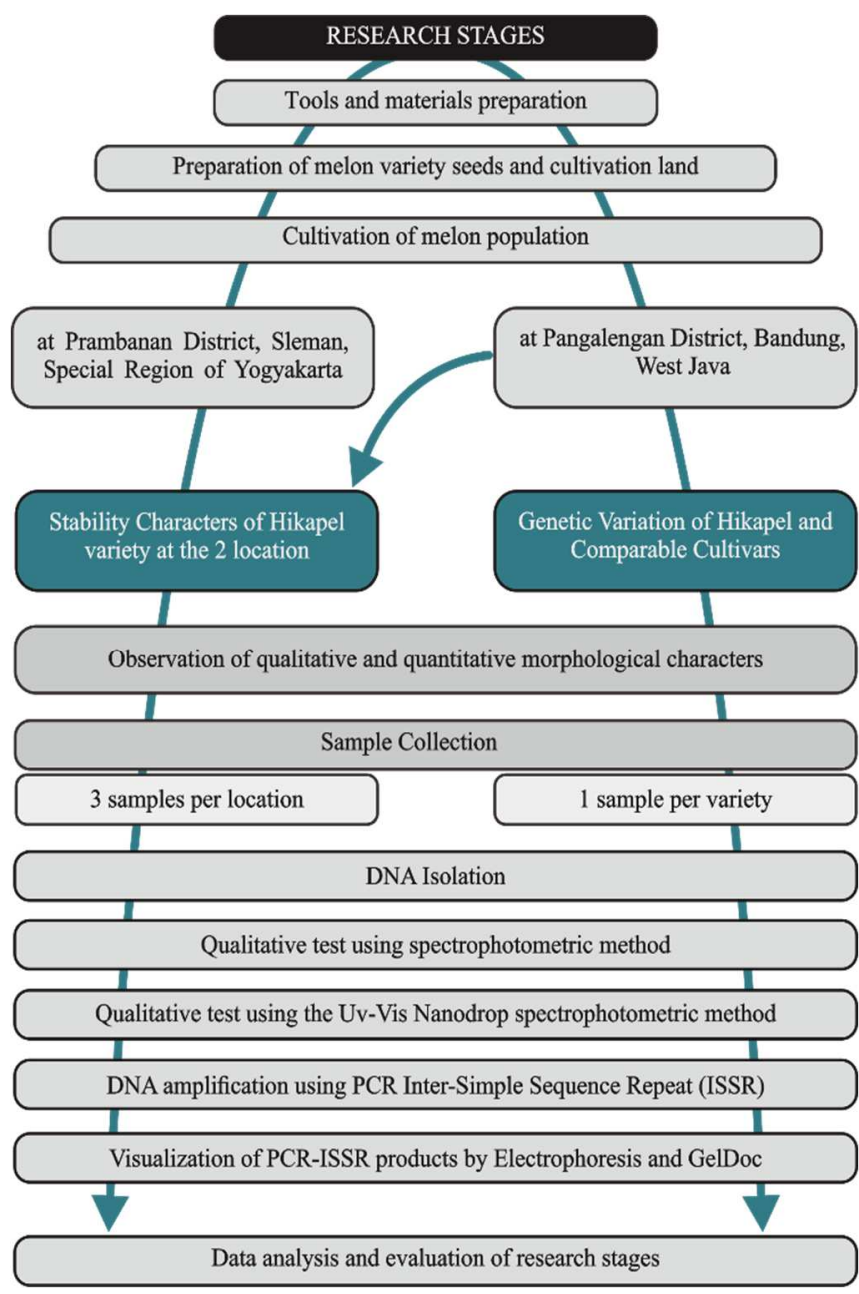

Fig. 1 Research stages

\section{B. Observation of Morphological Characters}

The research using direct observation methods aims to identify morphological characters. The plant samples observed were 12 individuals (4 samples per replication). $10 \%$ of the total population of 120 plants per cultivar. The morphological characters observed based on the official document of the melon testing guide (PVT/PPI/9/1) were 40 characters consist of 15 quantitative characters and 25 qualitative characters. Identification of morphological characters to obtain information on the characteristics of each cultivar as a marker that differentiates one another.

\section{Identification of Molecular Characters}

Evaluation of genetic variation used 1 leaf sample randomly for each cultivar population. Meanwhile, to identify the candidate cultivars' stability, 3 leaf samples were used, which were planted at different locations. The leaf samples were collected from the population 3-4 weeks old and stored in a freezer at $20^{\circ} \mathrm{C}$.

Identification of molecular characters includes DNA isolation, spectrophotometric tests, DNA amplification, and visualization of DNA fragments with electrophoresis and GelDoc. DNA isolation used the Nucleon Phytopure Kit, and the procedure followed the DNA isolation protocol for melons from the research of [10] with modifications. The concentration and purity test were carried out at the Genetic Engineering Laboratory of UGM Graduate School using a Nanodrop UV-Vis spectrophotometer (NanoVue 4282 V2.0.4 Beckman).

DNA amplification was carried out at the Laboratory of Genetics and Breeding, Faculty of Biology, UGM using the BOECO Thermal Cycler TC-PRO PCR machine. In this study, 5 ISSR primers were used, namely UBC 807, UBC 808, UBC 810, UBC 812, and UBC 825, which refer to previous studies [11] and about genetic variation in Cucurbitaceae [12]. ISSR (Inter-Simple Sequence Repeat) is a PCR-based molecular marker in the form of a region in the genome that is flanked by microsatellite sequences. The PCR amplification process in this region using a single primary produces amplification products used as a multilocus marker system in studying genetic variation, genetic diversity, phylogeny, genome mapping, and biological evolution in organisms [13]. The ISSR application is also used to detect genomic stability and hybridization assessments in various plant and animal species. ISSR has a higher sensitivity than RAPD in the detection of genetic diversity at a low level even though it is economically and conveniently the same as the RAPD technique. ISSR can detect more DNA loci and bands than RAPD primers, and amplifying the sequences between microsatellites can quickly distinguish closely related individuals [14].

The results of DNA amplification were further processed by the $2 \%$ agarose gel of the electrophoresis method. The electrophoresis method is the migration of charged particles or molecules based on the size of the molecules in the electric field to form molecular fractionation. The migration process at a voltage of 50 volts for 55 minutes. DNA migration is complete when the DNA fragment reaches $2 / 3$ the length of the agarose gel.

Visualization of electrophoresis results using GelDoc, which is connected to the Optilab application. The size of the DNA fragment formed is adjusted to the size of the DNA marker, whose size is known in units of base pairs (bp). The 
DNA marker used in this study was the Vivantis 100 bp ladder marker with a marker size range of $100-1000 \mathrm{bp}$.

\section{Evaluation and Data Analysis}

Quantitative morphological characters were analyzed using SPSS software with One Way Anova at the 1\% significance level with further LSD and Duncan tests. Qualitative morphological characters were processed using Microsoft Excel 365 student edition software. The morphological data obtained were used to identify and identify between cultivars to differentiate one from another [15].

Analysis of molecular characters with data of electrophoresis results converted into a 0-1 matrix (binary code). The scoring results were analyzed using the MVSP 3.1 program using the Jaccard coefficient method to determine the level of genetic relationship [16]. Fragment size analysis used Microsoft Excel 365 student edition software to determine amplified DNA levels. All stages of the research were carried out correctly by following the provisions of genetic research on melons even though with a limited time due to the Covid-19 Pandemic.

\section{RESULTS AND DISCUSSION}

\section{A. Identification of Morphological Characters}

The diversity of morphological characters was used to determine the differences between melon cultivars based on 50 morphological characters tested following the terms of release of melon cultivars PVT / PPI / 9/1. The diversity of a cultivar is caused by 2 main factors, namely genetics and the environment. The individual genotype determines the morphological characters expressed. The inheritance of the trait is controlled by some qualitative or quantitative genes and the environmental factors that influence them.

In this study, the assumptions used in the genotype (genetic factors) code for qualitative characters. Quantitative characters are controlled by environmental factors and several minor genes [15]. It has been reported that the QTL locus (quantitative trait locus) regulates the expression of a plant's character, such as s flowering time, seed size, and seed dispersal in maize, rice, and sorghum; and growth habit, photoperiod sensitivity, and dormancy in common bean [17].

TABLE I

MORPHOlOGiCAl CHARACTERS OF MELON CUltivarS

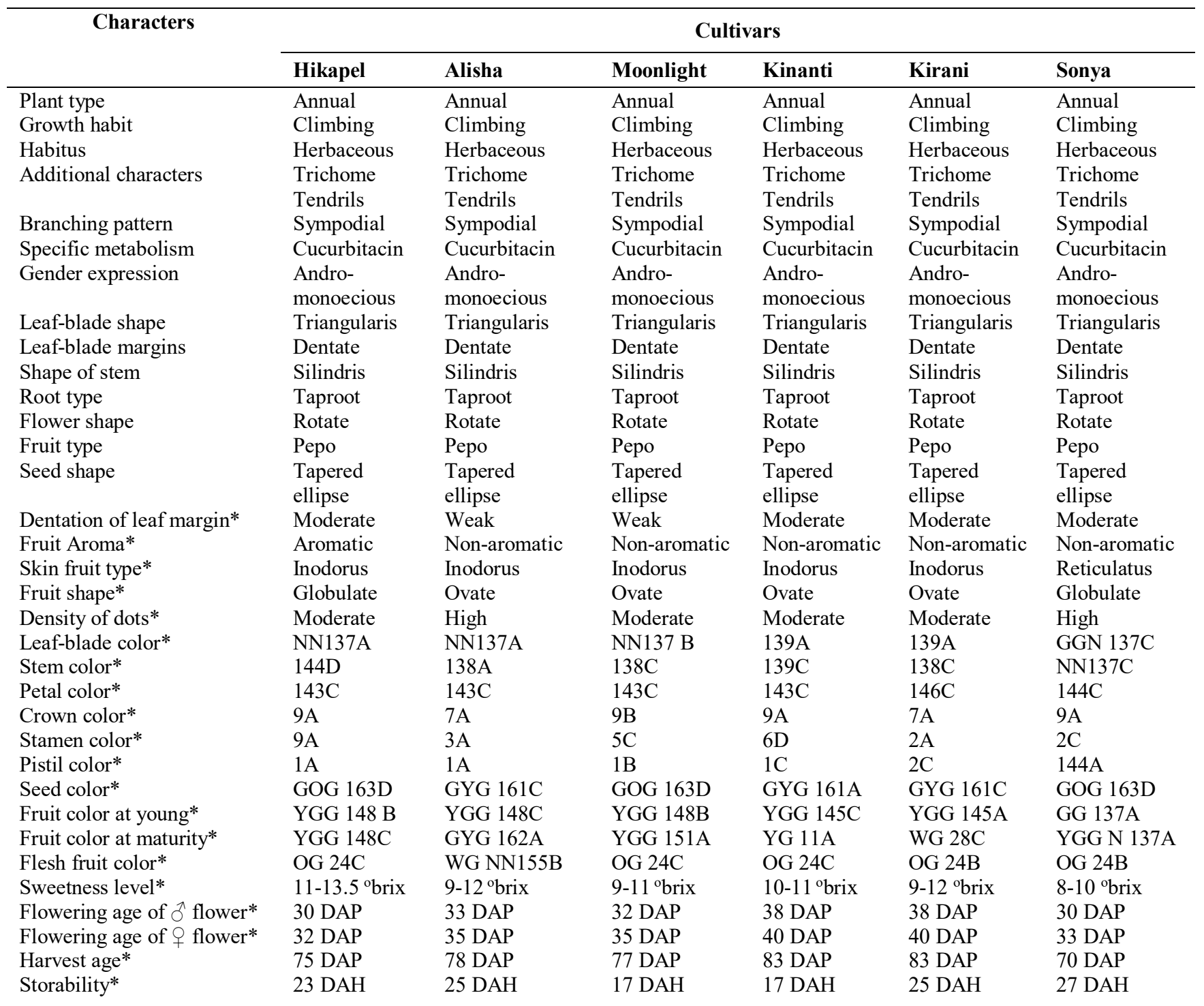




\begin{tabular}{|c|c|c|c|c|c|c|}
\hline Leaf blade area $\left(\mathrm{cm}^{2}\right)^{*}$ & $476.5 \pm 46.2^{\mathrm{b}}$ & $599.3 \pm 72.4^{\mathrm{d}}$ & $395.9 \pm 34.1^{\mathrm{a}}$ & $475.9 \pm 68.3^{\mathrm{b}}$ & $474.9 \pm 35.3^{b}$ & $522.3 \pm 38.7^{\mathrm{c}}$ \\
\hline Terminal cup $(\mathrm{cm})^{*}$ & $7.6 \pm 0.7^{\mathrm{c}}$ & $5.1 \pm 0.6^{\mathrm{a}}$ & $6.4 \pm 0.7^{\mathrm{b}}$ & $6.6 \pm 0.6^{\mathrm{b}}$ & $7.8 \pm 0.6^{\mathrm{c}}$ & $8.2 \pm 0.8^{c}$ \\
\hline Length of petiole $(\mathrm{cm})^{*}$ & $8.0 \pm 1.3^{c}$ & $8.3 \pm 1.5^{\mathrm{c}}$ & $5.4 \pm 1.4^{\mathrm{ab}}$ & $16.5 \pm 2.1^{\mathrm{b}}$ & $15.0 \pm 1.1^{\mathrm{a}}$ & $19.1 \pm 1.2^{\mathrm{c}}$ \\
\hline Diameter of stem $(\mathrm{cm})^{*}$ & $0 \pm 0.1^{\mathrm{ab}}$ & $.1 \pm 0.1^{\mathrm{ab}}$ & $1.1 \pm 0.1^{\mathrm{ab}}$ & $1^{\mathrm{a}}$ & $1.0 \pm 0.1^{\mathrm{ab}}$ & $1 \pm 0.1^{\mathrm{b}}$ \\
\hline er of lateral branches* & $.5 \pm 1.6^{\mathrm{c}}$ & $5^{\mathrm{c}}$ & 7 & $6^{\mathrm{a}}$ & & \\
\hline Ler & $5^{\mathrm{a}}$ & $9^{b}$ & & $6^{\mathrm{b}}$ & $44^{\mathrm{a}}$ & $08^{\mathrm{b}}$ \\
\hline & 0.73 & $1^{\mathrm{c}}$ & & & $0^{\mathrm{b}}$ & 0. \\
\hline & $5^{\mathrm{a}}$ & $d$ & & $11.89 \pm 1.02^{b}$ & 11 & $57^{b}$ \\
\hline & $4^{\mathrm{abc}}$ & 9.94 & $10.71 \pm 0.18^{b c}$ & $9.50 \pm 0.39^{\mathrm{a}}$ & 9.6 & $2.98^{\mathrm{d}}$ \\
\hline $\mathrm{W}$ & 2.5 & $2.85 \pm$ & $3.27 \pm$ & $2.67=$ & 2. & $.25^{\mathrm{c}}$ \\
\hline $\mathrm{We}$ & $6.2^{\mathrm{a}}$ & $58.5^{\mathrm{c}}$ & $.1^{\mathrm{b}}$ & $705 \pm$ & 65 & $110^{d}$ \\
\hline Diameter of pistil $(\mathrm{mm})^{*}$ & $16.78 \pm 4.75^{b}$ & $7.87 \pm 1.24^{\mathrm{a}}$ & $16.37 \pm 2.76^{\mathrm{b}}$ & $7.31 \pm 1.37^{\mathrm{a}}$ & $15.48 \pm 4.83^{b}$ & $16.79 \pm 2.91^{\mathrm{b}}$ \\
\hline of peduncle $(\mathrm{mm})^{*}$ & $9.79 \pm 0.58^{b}$ & $9.23 \pm 0.83^{b}$ & $12.67 \pm 1.34^{\mathrm{d}}$ & $8.02 \pm 0.70^{\mathrm{a}}$ & $11.08 \pm 1.62^{\mathrm{c}}$ & $12.25 \pm 1.88^{\mathrm{d}}$ \\
\hline Thickness of skin fruit (mm)* & $1.75 \pm 0.45^{\mathrm{a}}$ & $1.50 \pm 0.52^{\mathrm{a}}$ & $3.17 \pm 0.84^{b}$ & $3.17 \pm 1.19^{b}$ & $2.0 \pm 0.60^{\mathrm{a}}$ & $4.08 \pm 1.31^{\mathrm{c}}$ \\
\hline Seed's area $\left(\mathrm{cm}^{2}\right)^{*}$ & $0.58 \pm 0.04^{\mathrm{e}}$ & $0.51 \pm 0.04^{\mathrm{d}}$ & $0.42 \pm 0.02^{\mathrm{a}}$ & $0.52 \pm 0.02^{\mathrm{d}}$ & $0.44 \pm 0.02^{b}$ & $0.48 \pm 0.03^{\mathrm{c}}$ \\
\hline
\end{tabular}

Based on observations (Table 1), the characters of the Cucumis melo species are maintained in all tested cultivars. Referring to the publication of [18], these characters are plant type and growth, branching type, specific metabolism, gender expression, additional characters, and the type and shape of organs in general. Character diversity indicates the diversity between one cultivar and another.

Based on Table 1, there are 35 different characters between cultivars (marked with ${ }^{*}$ ) consisting of 20 qualitative and 15 quantitative characters. A cultivar does not need many diagnostic characters to be called a variety. However, the variety category refers to new, unique, stable special characteristics in each generation and uniform in a population. Hikapel as a new melon engineered through plant breeding, has many diagnostic characters from other cultivars (Figure 2 and Figure 3). These characters include margin size, aroma, fruit type, shape, dot density, organ color, and quantitative character.

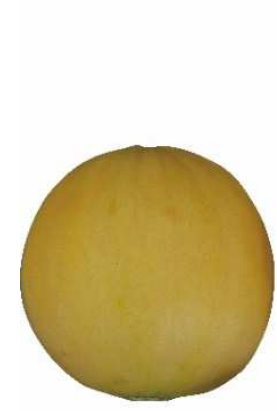

HIKAPEL

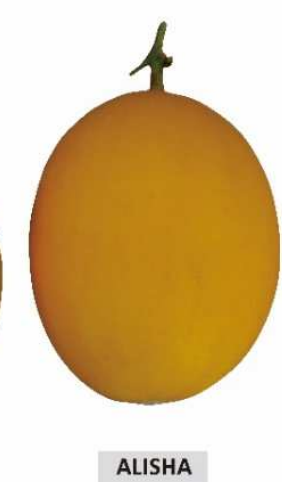

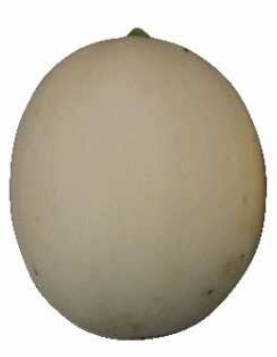

KIRANI

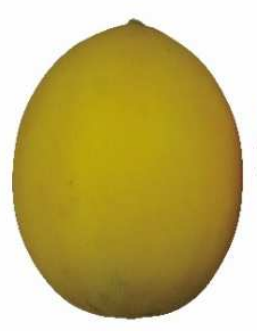

KINANTI

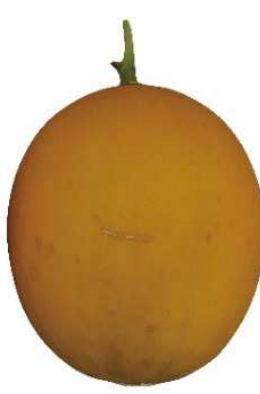

MOONLIGHT

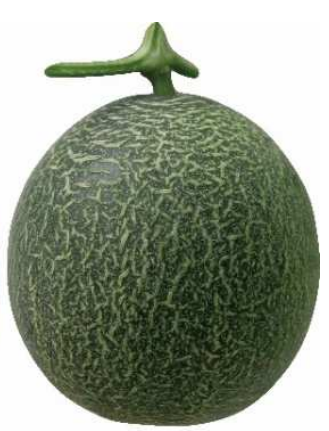

SONYA

Fig. 2 Fruit morphological character (outward appearance) of melon cultivars

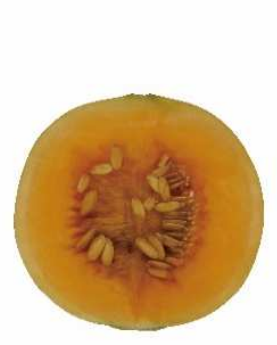

HIKAPEL

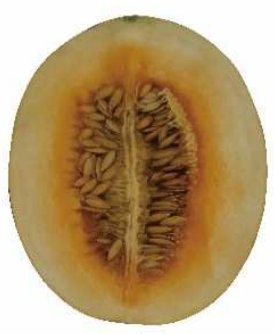

ALISHA

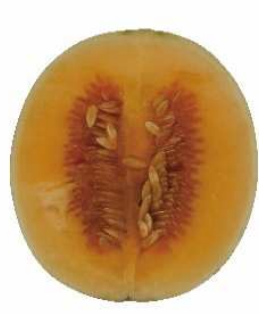

KIRANI

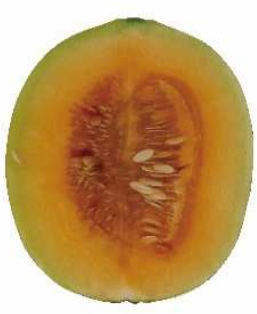

KINANTI

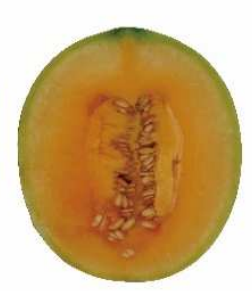

MOONLIGHT

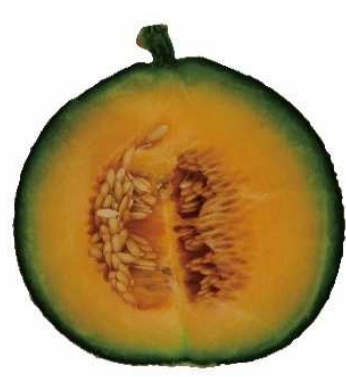

SONYA

Fig. 3 Fruit morphological character (inner appearance) of melon cultivars

The aromatic character was only found in Hikapel which developed along with the fruit maturity stage. This special character comes from Hikapel's ancestor, namely the GMP (Gama Melon Parfum) cultivar. The aroma of melon has been identified as coming from volatile compounds dominated by acetic esters and non-acetic esters [19]. In certain conditions, the turbine which is the main character of the GMP cultivar still appears in the Hikapel cultivar, although in an exceedingly small percentage. This character is very important as a source of germplasm for assembling superior melon varieties to improve the quality of melon products.

Hikapel has a globular shape with smooth fruit skin without a net. Usually referred to in the winter melon group with the character of the inodorus melon skin. The small fruit size of the handgrip with a creamy yellow colour makes the character of this melon an asset to develop the market-popular plum melon. Color variations in both the fruit skin and melon pulp are influenced by carotenoid and flavonoid pigments, especially $\beta$-carotene and chlorophyll pigments [20]. The 
color combinations observed are the result of the combination of pigments in the two grub (carotenoids and flavonoids) ([21]; [6]).

The characteristics of the Hikapel results of cultivation in 2018. same, when compared to references [22], are aromatic fruit, handy melon, crisp fruit texture, long storage, and orange fruit color. Besides, the diagnostic characters of Hikapel compared to another cultivar is the age of the plant is too short. The male flowering time is 30 days after plantationDAP and the female 32 DAP. So that the harvest time can be accelerated and productivity increases.

\section{B. Molecular Characters of Melon Cultivars}

Molecular analysis of genotype character was conducted using five ISSR primers. This study used the ISSR primer because it has several advantages compared to other methods of analysis. The PCR amplification process in this region using a single primer produces amplification products that are used as a multilocus marker system in the study of genetic variation, genetic diversity, phylogeny, genome mapping, and biological evolution in organisms [23]. The ISSR application is also used to detect genomic stability and hybridization assessments in various plant and animal species [24].

ISSR has a higher sensitivity than RAPD in the detection of genetic diversity at a low level even though it is economically and conveniently the same as the RAPD technique. ISSR can detect more DNA loci and bands than RAPD primers, and amplifying the sequences between microsatellites can quickly distinguish closely related individuals [25].

TABLE II

POLIMORPHIC RATE OF MELON CULTIVARS

\begin{tabular}{lllll}
\hline Primer ISSR & $\begin{array}{l}\text { Number of } \\
\text { loci }\end{array}$ & $\begin{array}{l}\text { Polymorphic } \\
\text { loci }\end{array}$ & $\begin{array}{l}\text { Polymorphic } \\
\text { rate (\%) }\end{array}$ & $\begin{array}{l}\text { Fragment } \\
\text { size (bp) }\end{array}$ \\
\hline UBC-807 & 6 & 3 & 50.00 & $321-1320$ \\
UBC-808 & 12 & 10 & 83.33 & $398-1517$ \\
UBC-810 & 6 & 5 & 83.33 & $636-1196$ \\
UBC-812 & 6 & 5 & 83.33 & $424-1320$ \\
UBC-825 & 14 & 14 & 100 & $499-1301$ \\
Rerata & 8.8 & 7.4 & 79.998 & - \\
Total & 44 & 37 & - & - \\
\hline
\end{tabular}

The number of DNA fragments amplified by 5 ISSR primers is 45 fragments consist of 40 polymorphic and 5 monomorphic DNA fragments, as shown in Table 2. The lowest percentage of polymorphism was produced by UBC 807 primers with a value of $50 \%$, and the highest was produced by UBC 825 with a value of $100 \%$. Primers with a high level of polymorphism $\geq 50 \%$ have a low similarity value with high genetic variation. Meanwhile, primers that produce low polymorphism $(\leq 50 \%)$ show a high similarity value. All primers generate a percentage of polymorphism above $50 \%$, which indicates all primers, i.e., UBC 807 , UBC 808, UBC 810, UBC 812, and UBC 825, can be used as molecular markers for testing genetic variation in melons. The high level of polymorphism indicates the high genetic variation between melon varieties.

\section{Genetic Relationship of Melon Cultivars}

Table 3 shows the genetic distance, which is a reconstruction of the similarity matrix from the UPGMA test results with the Jaccard Coefficient. The smallest genetic distance obtained was between cultivar Kirani - Kinanti with a value of 0.53 . Meanwhile, the highest genetic distance that showed a high difference in both phenotypic and molecular characters was between Alisha and Sonya cultivars, with a value of 0.71 . The genetic distance between Hikapel and other melon cultivars is high, which is above 0.60 . The higher the genetic distance number, the wider the character difference. The decreasing similarity index between cultivars also shows this value. The overall value of the genetic distance between cultivars is relatively high (above 50\%), so it can be assumed that the genetic characters between cultivars are different and can become the basis for launching new varieties. The genetic relationship between cultivars is shown in Figure 4.

TABLE III

Genetic Distance of Melon Cultivars

\begin{tabular}{lllllll}
\hline & Hikapel & Alisha & Moonlight & Kinanti & Kirani & Sonya \\
\hline HK & 0,00 & & & & & \\
ALS & 0,67 & 0,00 & & & & \\
MLG & 0,67 & 0,64 & 0,00 & & & \\
KNT & 0,66 & 0,61 & 0,58 & 0,00 & & \\
KRN & 0,62 & 0,59 & 0,62 & 0,50 & 0,00 & \\
SO & 0,70 & 0,71 & 0,65 & 0,69 & 0,67 & 0,00 \\
\hline
\end{tabular}

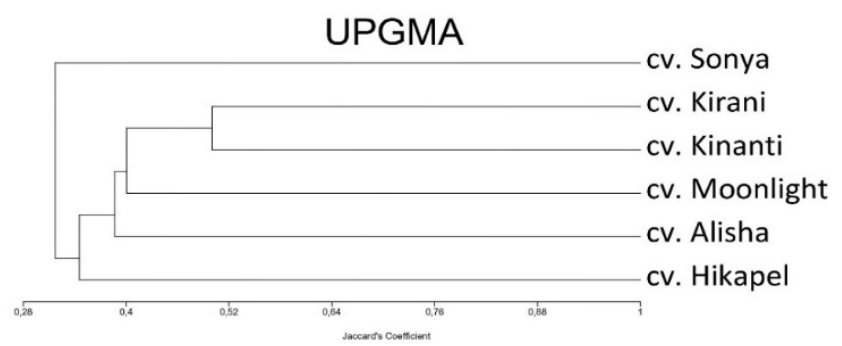

Fig. 4 Phenetic relationship of melon cultivars based on ISSRs markers and morphological characters using the UPGMA method

Based on Figure 4 regarding the phenetic relationship in six melon cultivars divided into 2 main clusters: winter melons and netted melons. Winter melon is a melon group with smooth, shiny, easily damaged fruit skin characteristics that do not last long in storage [9]. Hikapel, Alisha, Moonlight, Kinanti, and Kirani are cultivars of this type of melon. Kirani and Kinanti have a relatively close phenetic relationship with a similarity percentage value of $50 \%$. Sonya has the lowest similarity value with other melon cultivars. It is because Sonya belongs to the group of reticulatus melons (netted melons). After all, the outer shell has a net character. This character modifies the hardened epidermal callus and is regulated by ethylene activity [26]. The number and thickness of the nets on the Sonya increase gradually as the fruit develops towards its full maturity. The net character acts as fruit protection against external influences, which causes this type of fruit more resistant and durable (Table 1) compared to inodorus type melons.

Hikapel as a candidate melon, has a similarity index that is far from that of other melons, as shown in Figure 4. This indicates that Hikapel has no phenetic relationship with other cultivars. This data is reinforced by the very significant differences in morphological characters between the cultivars observed (Figure 2 and Figure 3). The Hikapel candidate cultivar has superior characteristics that other cultivars do not have. This character is a source of germplasm that can be further developed to support agricultural development in Indonesia. Also, genetic information data is indispensable in 
the development of genetic science, especially plant breeding. Advances in molecular genetics and marker systems have accelerated the rate of plant breeding. This can solve global crop cultivation problems due to biotic and abiotic stresses, one of which is extreme and erratic climate change. Even today, there is the term genomics-assisted breeding (GAB). $\mathrm{GAB}$ is a term for plant breeding that utilizes genomic data [27]. The availability of genomic data sets such as informative molecular characters can accelerate the science of plant breeding.

\section{Stability Character of Hikapel}

The stability and uniformity test of Hikapel characters as a variety requirement was carried out at two different locations and cultivation methods: (1) Prambanan, Sleman, Yogyakarta from May to June 2019 with conventional cultivation and (2) Pangalengan, Bandung, West Java from July to October 2019 with modern hydroponic cultivation, as shown in Table 4.

TABLE IV

ENVIRONMENTAL CONDITIONS AT THE TWO CULTIVATION LOCATIONS

\begin{tabular}{lll}
\hline Location & $\begin{array}{l}\text { Pangalengan, Bandung, } \\
\text { West Java, Indonesia }\end{array}$ & $\begin{array}{l}\text { Prambanan, Sleman, } \\
\text { Yogyakarta, Indonesia }\end{array}$ \\
\hline Time & July-October 2019 & May-June \\
\hline Altitude & 1432 mamsl & 115 mamsl \\
Latitude & $7.20 \mathrm{~S}, 107.55 \mathrm{E}$ & $7.80 \mathrm{~S}, 110.51 \mathrm{E}$ \\
Temperature & $23.27^{\circ} \mathrm{C}$ & $25.17{ }^{\circ} \mathrm{C}$ \\
Humidity & $66.86 \%$ & $79.52 \%$ \\
Rainfall & $0.5 \mathrm{~mm}$ & $0.5 \mathrm{~mm}$ \\
Length of sun & 7.7 hours & 7.7 hours \\
exposure & & \\
Methods & Hydrophonic & Conventional \\
\hline
\end{tabular}

The average high humidity in the lowlands indicates the high growth of fungi compared to the highlands. The planting method between the two different locations determines the time of cultivation and the storability of fruit. The application of hydroponic systems has several advantages include (1) resource efficiency, (2) efficient nutrition, (3) optimal nutrition, (4) easy pest control, (5) controlled nutrition, and (7) continuous and scheduled production results [28]. Direct observations obtained that the plants grown using a hydroponic system with a closed greenhouse condition were healthier and better than those planted in conventional screen houses.

The research results that have been carried out are presented in Table 5 regarding the stability characters of the Hikapel cultivar cultivated in different locations. The difference in character lies in the quantitative character, color character, harvest age, and shelf life of the fruit.

The harvest age of the two varieties at an altitude of 1432 masl with the hydroponic method is longer than conventional methods. This can be due to the adequate supply of nutrients in the hydroponic method, which causes plants to be in comfortable conditions. As a result, the vegetative phase is maintained (indicated by the character of the larger leaves and stems), and the generative phase is inhibited. The variation in melon age depends on several factors, namely genetics, environment, and a combination of cultivation methods.

The shelf life of the fruit is directly related to the respiration process and ethylene production. According to its type, melon is a climacteric fruit group characterized by decreased $\mathrm{CO}_{2}$ produced in the growth phase and will increase just before senescence.

TABLE V

Stability of MORPHOLOGICAL CHARACTERS OF HiKaPEl CUlTiVAR AT DIFFERENT LOCATIONS

\begin{tabular}{|c|c|c|}
\hline \multirow[b]{2}{*}{ Characters } & \multicolumn{2}{|c|}{ Cultivation Location } \\
\hline & $\begin{array}{c}\text { Nudira, Pangalengan, } \\
\text { Bandung, West Java, } \\
\text { Indonesia }\end{array}$ & $\begin{array}{c}\text { Mutihan, } \\
\text { Prambanan, } \\
\text { Sleman, } \\
\text { Yogyakarta, } \\
\text { Indonesia }\end{array}$ \\
\hline Plant type & Annual & Annual \\
\hline Growth habit & Climbing & Climbing \\
\hline Habitus & Herbaceous & Herbaceous \\
\hline \multirow[t]{2}{*}{ Additional characters } & Trichome & Trichome \\
\hline & Tendrils & Tendrils \\
\hline Branching pattern & Sympodial & Sympodial \\
\hline Specific metabolism & Cucurbitacin & Cucurbitacin \\
\hline Gender expression & Andro-monoecious & Andro-monoecious \\
\hline Leaf-blade shape & Triangular & Triangular \\
\hline Leaf-blade margins & Dentate & Dentate \\
\hline Shape of stem & Cylindrical & Cylindrical \\
\hline Root type & Taproot & Taproot \\
\hline Flower shape & Rotate & Rotate \\
\hline Fruit type & Pepo & Pepo \\
\hline Seed shape & Tapered ellipse & Tapered ellipse \\
\hline $\begin{array}{l}\text { Dentation of leaf } \\
\text { margin }\end{array}$ & Moderate & Moderate \\
\hline Fruit Aroma & Aromatic & Aromatic \\
\hline Skin fruit type & Inodorus & Inodorus \\
\hline Fruit shape & Globulate & Globulate \\
\hline Density of dots & Moderate & Moderate \\
\hline Leaf-blade color* & NN137A & NN137B \\
\hline Stem color* & 144D & $146 D$ \\
\hline Petal color* & $143 \mathrm{C}$ & 145B \\
\hline Crown color* & $9 \mathrm{~A}$ & $12 \mathrm{~A}$ \\
\hline Stamen color* & $9 \mathrm{~A}$ & $12 \mathrm{~A}$ \\
\hline Pistil color* & $1 \mathrm{~A}$ & $12 \mathrm{~A}$ \\
\hline Fruit color at young & YGG 148 B & YGG 148 B \\
\hline $\begin{array}{l}\text { Fruit color at } \\
\text { maturity }\end{array}$ & YGG 148C & YGG 148C \\
\hline Flesh fruit color* & OG $24 \mathrm{C}$ & OG $24 \mathrm{C}$ \\
\hline Sweetness level* & $11-13.5^{\circ}$ brix & $9-14^{\circ}$ brix \\
\hline Harvest age* & 75 DAP & $62 \mathrm{DAP}$ \\
\hline Storability* & $23 \mathrm{DAH}$ & $18 \mathrm{DAH}$ \\
\hline $\begin{array}{l}\text { Leaf blade area } \\
\left(\mathrm{cm}^{2}\right)^{*}\end{array}$ & $476.5 \pm 46.2$ & $337.19 \pm 6,97$ \\
\hline $\begin{array}{l}\text { Diameter of stem } \\
(\mathrm{cm})^{*}\end{array}$ & $1.0 \pm 0.1$ & $0,92 \pm 0,02$ \\
\hline $\begin{array}{l}\text { Width of flesh fruit } \\
(\mathrm{cm})^{*}\end{array}$ & $2.51 \pm 0.24$ & $2,40 \pm 0,42$ \\
\hline Weight of fruit $(\mathrm{g})^{*}$ & $704.6 \pm 96.2$ & $804 \pm 207,07$ \\
\hline
\end{tabular}

Based on the comparative research data on the height and fruit storage capacity shown in Table 5 , it was found that the fruit storage capacity was much higher in the highlands compared to the lowlands. This is due to several factors, including temperature, levels of $\mathrm{O}_{2}$ and $\mathrm{CO}_{2}$, and humidity. Cold temperatures in the highlands inhibit the rate of fruit respiration. Besides, oxygen and humidity levels in the highlands are lower than in the lowlands, so respiration rates are inhibited. As a result, fruit ripening is inhibited.

The genetic diversity is indicated by differences in the number, pattern, and size of amplified DNA fragments in each used primer. Polymorphisms in the DNA band are variations resulting from the amplification process during PCR. The thickness of the DNA band is influenced by the number of cycles in the amplification process. Each cycle is a duplication of the number of DNA targets. DNA fragments formed and in 
excess conditions can cause the fragments to coincide with one another during visualization.

Consequently, the determination of the size and number of amplified fragments is biased and unsuitable. According to Reference, using an excessive number of cycles can increase the number of non-target products, and the PCR amplification efficiency is not perfect $100 \%$. This is due to many target templates and the limited number of DNA polymerase enzymes, which can even allow reannealing of the target DNA strands. The determination of the number of cycles was based on previous research on melons and the Cucurbitaceae family.

The difference in annealing temperature in each primer is due to the difference in each primer's melting temperature (Tm). Melting temperature is the temperature required for half the duplex primer to dissociate. Primary annealing temperature ( $\mathrm{Ta})$ estimates the temperature at which the primer can bind to the DNA template stably [29]. The primary concentration used in this study was $10 \mu \mathrm{M}$ with a template DNA concentration of $200 \mathrm{ng} / \mu \mathrm{l}$. Table 6 . show the number of DNA fragments of Hikapel cultivar amplified by 5 ISSR primers was 23 DNA fragments with one polymorphic DNA fragment and 22 monomorphic DNA fragments. The highest percentage of polymorphism was produced by UBC-825 primers $(16.67 \%)$, and the lowest was produced by four ISSR primers i.e., UBC-807, UBC-808, and UBC-810, and UBC$825(0 \%)$. The mean polymorphic percentage of the 5 primers was $3.33 \%$. The low value of polymorphism $(\leq 50 \%)$ in Hikapel cultivar indicates high genetic stability and uniformity.

TABLE VI

POLYMORPHiC RATE OF HIKAPEL CULTIVARS AT DifFERENT CULTIVATION LOCATIONS

\begin{tabular}{|c|c|c|c|c|c|c|}
\hline $\begin{array}{l}\text { ISSR } \\
\text { Prim } \\
\text { ers }\end{array}$ & $\begin{array}{l}\text { Sequen } \\
\text { ce (5' - } \\
\left.3^{\prime}\right)\end{array}$ & $\begin{array}{l}\text { Annealing } \\
\text { temperatur } \\
\mathrm{e}\left({ }^{\circ} \mathrm{C}\right)\end{array}$ & $\begin{array}{l}\text { Total } \\
\text { number } \\
\text { of loci }\end{array}$ & $\begin{array}{l}\text { Polym } \\
\text { orphic } \\
\text { loci }\end{array}$ & $\begin{array}{l}\text { Polymor } \\
\text { phic rate } \\
(\%)\end{array}$ & $\begin{array}{l}\text { DNA } \\
\text { fragment } \\
\text { size (bp) }\end{array}$ \\
\hline $\begin{array}{l}\text { UBC } \\
-807\end{array}$ & $(\mathrm{AG})_{8} \mathrm{~T}$ & 50 & 4 & 0 & 0 & $339-587$ \\
\hline $\begin{array}{l}\text { UBC } \\
-808\end{array}$ & $\begin{array}{l}(\mathrm{AG})_{8} \\
\mathrm{C}\end{array}$ & 50 & 7 & 0 & 0 & $388-1478$ \\
\hline $\begin{array}{l}\text { UBC } \\
-810\end{array}$ & $(\mathrm{GA})_{8} \mathrm{~T}$ & 46,2 & 3 & 0 & 0 & $668-841$ \\
\hline $\begin{array}{l}\text { UBC } \\
-812\end{array}$ & $\begin{array}{l}(\mathrm{GA})_{8} \\
\mathrm{~A}\end{array}$ & 46,2 & 3 & 0 & 0 & $415-889$ \\
\hline $\begin{array}{l}\text { UBC } \\
-825\end{array}$ & $(\mathrm{AC})_{8} \mathrm{~T}$ & 40 & 6 & 1 & 17 & $540-1393$ \\
\hline $\begin{array}{l}\text { Aver } \\
\text { age }\end{array}$ & - & - & 5 & 4 & 3,3 & - \\
\hline Total & - & - & 23 & 22 & - & - \\
\hline
\end{tabular}

The phenetic relationship of the Hikapel cultivar is presented in Figure 5.

\section{UPGMA}

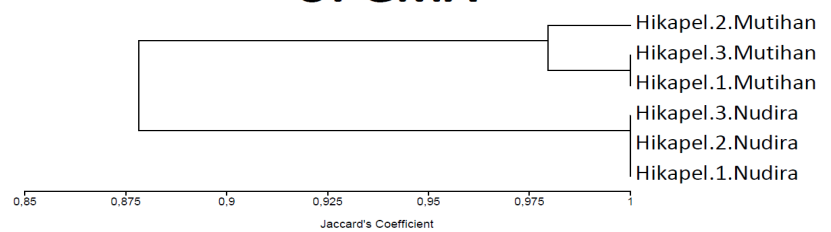

Fig. 5 Phenetic relationship of melon Hikapel cultivars based on ISSRs markers and morphological characters using the UPGMA method

Based on the results of this study, 2 main clusters i.e., the cluster of Hikapel cultivated by Nudira Sumber Daya Indonesia in Bandung, West Java, and the cluster of Hikapel cultivated in Mutihan, Sleman, Yogyakarta. The first cluster consists of the Hikapel cultivate by GH Nudira Sumber Indonesia has a very high phenetic relationship with a percentage value of $100 \%$ similarity. The second cluster consists of cultivated at Mutihan, Sleman, Yogyakarta. Individuals with the name of sample Hikapel.1. Mutihan (code: HK.1.M) and Hikapel.3. Mutihan (code: HK.3.M) have a percentage value of $100 \%$ similarity. Meanwhile, Hikapel.2. Mutihan individual (code: HK.2.M) has a $98 \%$ similarity. The cluster of Hikapel cultivate by Nudira Sumber Daya Indonesia in Bandung, West Java, and the cluster of Hikapel cultivate in Mutihan, Sleman, Yogyakarta had a similarity percentage of $88 \%$. This value is above $70 \%$, indicating that all samples of Hikapel are uniform and have a close phonetic relationship. The differences in location and cultivation method do not cause genetic changes to maintain phenotypic characters.

\section{CONCLUSION}

The different diagnostic characters of the Hikapel compared to other varieties are globular shape with creamcolored skin, aromatic fruit, small size, high sweetness level, and short harvest time. The Hikapel in the stability test characters remains stable and maintained at two different locations. The phenetic genetic relationship showed that all varieties were not close (under 50\%), and Hikapel had diagnostic characters as a new variety.

\section{REFERENCES}

[1] T. Osawa, "Perspectives on biodiversity informatics for ecology," Ecol. Res., vol. 34, no. 4, pp. 446-456, 2019, doi: 10.1111/14401703.12023 .

[2] J. Troudet, R. Vignes-Lebbe, P. Grandcolas, and F. Legendre, "The increasing disconnection of primary biodiversity data from specimens: How does it happen and how to handle it?," Syst. Biol., vol. 67, no. 6, pp. 1110-1119, 2018, doi: 10.1093/sysbio/syy044.

[3] D. Brown, I. Van den Bergh, S. de Bruin, L. Machida, and J. van Etten, "Data synthesis for crop variety evaluation. A review," Agron. Sustain. Dev., vol. 40, no. 4, 2020, doi: 10.1007/s13593-020-00630-7.

[4] B. C. Y. Collard and D. J. Mackill, "Marker-assisted selection: An approach for precision plant breeding in the twenty-first century," Philos. Trans. R. Soc. B Biol. Sci., vol. 363, no. 1491, pp. 557-572, 2008, doi: 10.1098/rstb.2007.2170.

[5] J. C. Dawson and G. K. Healy, "Flavour Evaluation for Plant Breeders," Plant Breed. Rev., vol. 41, pp. 215-261, 2017, doi: 10.1002/9781119414735.ch5.

[6] H. Chikh-Rouhou, I. Tlili, R. Ilahy, T. R'Him, and R. Sta-Baba, "Fruit quality assessment and characterization of melon genotypes," Int. J. Veg. Sci., vol. 00, no. 00, pp. 1-17, 2019, doi: 10.1080/19315260.2019.1692268.

[7] D. Neocleous, G. Ntatsi, and D. Savvas, "Physiological, nutritional and growth responses of melon (Cucumis melo L.) to a gradual salinity built-up in recirculating nutrient solution," J. Plant Nutr., vol. 40, no. 15, pp. 2168-2180, 2017, doi: 10.1080/01904167.2017.1346673.

[8] A. P. Saputri, W. A. Wibowo, and B. S. Daryono, "Phenotypical Characters and Biochemical Compound of Cucurbitacin Melon (Cucumis melo L. 'Gama Melon Parfum') Resulted from Breeding," AIP Conf. Proc., vol. 2260, 2020, doi: 10.1063/5.0017615.

[9] S. . Daryono, Budi Setiadi; Maryanto, Keanekaragaman dan Potensi Sumber Daya Genetik Melon. Yogyakarta: Gadjah Mada University Press, 2017.

[10] B. S. Daryono and K. T. Natsuaki, "Application of random amplified polymorphic DNA markers for detection of resistant cultivars of melon (cucumis melo) against cucurbitaceae viruses," Acta Hortic., vol. 588, no. January 2001, pp. 321-329, 2002, doi: 10.17660/ActaHortic.2002.588.52.

[11] B. S. Daryono and N. Nofriarno, "Pewarisan Karakter Fenotip Melon (Cucumis melo L. 'Hikapel Aromatis') Hasil Persilangan + 'Hikapel' 
dengan $\delta$ 'Hikadi Aromatik," Biosfera, vol. 35, no. 1, p. 44, 2018, doi: 10.20884/1.mib.2018.35.1.586.

[12] P. Innark, T. Ratanachan, C. Khanobdee, S. Samipak, and C. Jantasuriyarat, "Downy mildew resistant/susceptible cucumber germplasm (Cucumis sativus L.) genetic diversity assessment using ISSR markers," Crop Prot., vol. 60, pp. 56-61, 2014, doi: 10.1016/j.cropro.2014.03.003.

[13] M. Akash, N. Awad, and M. Kasrawi, "Genetic diversity among snake melon landraces (Cucumis Melo Var. Flexuosus) using molecular descriptors," Plant Biosyst., vol. 154, no. 2, pp. 206-212, 2020, doi: 10.1080/11263504.2019.1587536.

[14] G. C. Luz, D. K. Strioto, C. A. Mangolin, and M. de F. P. S. Machado, "ISSR markers to assess genetic diversity of cultivated populations from artificial selection of stevia rebaudiana (Bert.) bertoni," Breed. Sci., vol. 70, no. 4, pp. 508-514, 2020, doi: 10.1270/jsbbs. 20014.

[15] M. A. Sihaloho, D. S. Hanafia, E. Julianti, and M. Basyuni, "Morphological Characters of Local Origin Durian (Durio zibethinus Murr.) Fruits and Seeds from Central Tapanuli Regency, North Sumatra, Indonesia," Int. J. Adv. Sci. Eng. Inf. Technol., vol. 11, no. 1, pp. 213-222, 2021, doi: 10.18517/ijaseit.11.1.11211.

[16] M. Basyuni et al., "Cluster analysis of polyisoprenoid in oil palm (Elaeis guineensis) leaves in different land-uses to find the possible cause of yield gap from planting materials," Biodiversitas, vol. 19, no. 4, pp. 1492-1501, 2018, doi: 10.13057/biodiv/d190440.

[17] G. Acquaah, Principles of Plant Genetics and Breeding: Second Edition. 2012.

[18] E. Křístková, A. Lebeda, V. Vinter, and O. Blahoušek, "Genetic resources of the genus Cucumis and their morphological description (English-Czech version)," Hortic. Sci., vol. 30, no. No. 1, pp. 14-42, 2018, doi: 10.17221/3812-hortsci.

[19] C. Esteras, J. L. Rambla, G. Sánchez, A. Granell, and M. B. Picó, "Melon genetic resources characterization for rind volatile profile," Agronomy, vol. 10, no. 10, 2020, doi: 10.3390/agronomy10101512.

[20] N. Charoenchongsuk, D. Matsumoto, A. Itai, and H. Murayama, "Ripening characteristics and pigment changes in russeted pear fruit in response to ethylene and 1-MCP," Horticulturae, vol. 4, no. 3, pp. 114, 2018, doi: 10.3390/horticulturae4030022.

[21] A. S. Hermanns, X. Zhou, Q. Xu, Y. Tadmor, and L. Li, "Carotenoid Pigment Accumulation in Horticultural Plants," Hortic. Plant J., vol. 6, no. 6, pp. 343-360, 2020, doi: 10.1016/j.hpj.2020.10.002.

[22] A. F. Yusuf, W. A. Wibowo, A. S. Subiastuti, and B. S. Daryono, "Morphological Studies of Stability and Identity of Melon (Cucumis melo L.) 'Hikapel' and Comparative Cultivars," AIP Conf. Proc., vol. 2260, no. September 2020, doi: 10.1063/5.0017606.

[23] B. S. Daryono, A. S. Subiastuti, A. Fatmadanni, and D. Sartika, "Phenotypic and genetic stability of new indonesian melon cultivar (Cucumis melo L. 'Melonia') based on ISSR markers," Biodiversitas, vol. 20, no. 4, pp. 1069-1075, 2019, doi: 10.13057/biodiv/d200419.

[24] A. Etminan et al., "Genetic relationships and diversity among wild Salvia accessions revealed by ISSR and SCoT markers," Biotechnol. Biotechnol. Equip., vol. 32, no. 3, pp. 610-617, 2018, doi: 10.1080/13102818.2018.1447397.

[25] A. Mondal, T. Pal, and K. K. De, "Fluorescent Inter Simple Sequence Repeat (F-ISSR) markers and capillary electrophoresis to assess genetic diversity and relatedness within commercial sugarcane varieties," Int. J. Agric. Technol., vol. 14, no. 5, pp. 717-730, 2018.

[26] L. Ying Chang, S. Peng He, Q. Liu, J. Lin Xiang, and D. Feng Huang, "Quantifying muskmelon fruit attributes with A-TEP-based model and machine vision measurement," J. Integr. Agric., vol. 17, no. 6, pp. 1369-1379, 2018, doi: 10.1016/S2095-3119(18)61912-4.

[27] P. Fei Leng, T. Lübberstedt, and M. Liang Xu, "Genomics-assisted breeding - A revolutionary strategy for crop improvement," J. Integr. Agric., vol. 16, no. 12, pp. 2674-2685, 2017, doi: 10.1016/S20953119(17)61813-6.

[28] P. Sambo et al., "Hydroponic Solutions for Soilless Production Systems: Issues and Opportunities in a Smart Agriculture Perspective," Front. Plant Sci., vol. 10, no. July 2019, doi: 10.3389/fpls.2019.00923.

[29] W. L. Ng and S. G. Tan, "Inter-Simple Sequence Repeat (ISSR) markers: Are we doing it right?," ASM Sci. J., vol. 9, no. 1, pp. 30-39, 2015. 